\title{
The Effectiveness of the Teacher Professional Development Program in Implementing Curriculum 2013 in The Framework of STEM Education
}

\author{
Santi Setiani Hasanah*, Anna Permanasari, Riandi \\ Postgraduate School: Department of Science Education \\ Universitas Pendidikan Indonesia \\ Bandung, Indonesia \\ *santisetiani@upi.edu
}

\begin{abstract}
STEM (Science, Technology, Engineering, and Mathematics) learning is introduced in Indonesia to face the challenges of the 21st century. Teacher Professional Development Program (TPDP) is carried out by the Centre for Development and Empowerment of Teacher and Education Personnel (CDETEP) in Science to improve the competence of science teacher. The purpose of this study is to obtain information about the effectiveness of TPDP using a survey method. Respondents of this study were 120 program alumni. The results showed that 93\% of respondents stated that the program is effective to increase their competence, $70 \%$ of respondents stated that the training pattern is appropriate, and $94.2 \%$ of respondents were still implementing this STEM education in class. According to respondents, after implementing the STEM approach in the classroom, students' ability to collaborate, communicate, be critical, and be creative are well improved.
\end{abstract}

Keywords-STEM, teacher professional development

\section{INTRODUCTION}

Advances in science, technology, engineering, and mathematics (STEM) are projected to be the driving force of the future economic and overall well-being not only for advanced economies like the United States but also for growing economies worldwide, like Indonesia. For this reason, improving the quality of science learning is required to face 21 st-century challenges. It cannot be delayed anymore as the challenges keep growing. One of the efforts to improve science learning is by implementing STEM in the classroom. The STEM education could improve student's 21 st-century skills particularly collaborative, creative, communicative, responsibility, problem-solving, and critical thinking skills $[1,2]$. Besides, STEM education is also able to strengthen the implementation of Curriculum 2013 in Indonesia. This makes the role of the teacher essential, and thus, the teacher professional development (PD) program in STEM education is necessary. Several results of the research show that an excellence and continuous teacher PD program could improve student's learning outcomes $[3,4]$.
In Indonesia, it is quite difficult to implement STEM education since the level of teacher's knowledge regarding STEM education is low [5]. This may be caused by the insufficient numbers of teacher's training on STEM education. The teacher needs to be exposed more to STEM education through a teacher training program equipped with its training modules [6]. A teacher training program will be effective if it is continuous, the teacher is actively involved in the learning process, and there is a group discussion [7].

Several results of the research show that teachers admitted that they do not possess sufficient knowledge about STEM education since it has a wide and interconnected state [8]. Teacher PD is influenced by several aspects including teacher's perception, prior knowledge, and environment [9]. Many studies examined the factors that make PD effective. Avalos [10] classified the factors that affect the success of teachers' professional learning into three major types: contextual factors, structural features of the program, and process features. Examples of the contextual factors may include pressure from policy, and community [11], the school environment and support [12]. The structural features include the design of PD [13] and its duration [14]. The process features include tools that facilitate learning such as reflection processes as an instrument for teacher change, for example processes include narrative accounts, self-assessment, and portfolios [15].

With those reasons in mind, the researcher is interested in studying the effectiveness of a teacher professional development program in implementing curriculum 2013 in the framework of STEM education conducted by CDETEP in Science. The research questions are as follows.

- Is the implemented program effective in improving teacher's pedagogical competence?

- Has the training pattern been effective for the teacher to understand the STEM materials?

- How is the implementation of Curriculum 2013 integrated with STEM education in class? 


\section{METHODS}

\section{A. Research Methods}

This study employed a survey research method with a cross-sectional survey design, where the data are collected at one time. This method is appropriate in evaluating program implementation [16]. This study aims to find out the effectiveness of the teacher professional development program in implementing curriculum 2013 in the framework of STEM education.

To find out the effectiveness of a training program, the alumni of the respective training could be the respondents. They are asked to deliver their opinion regarding the implementation of the program, what they have learned, and whether the program improves their knowledge and skills [17].

The data collection technique used in this study was a questionnaire distributed using Google Form. The data analysis technique used in this study was recording the total number of respondents and calculating the percentage of each question item [18].

\section{B. Respondent}

The respondents of the study were 120 alumni of Training on the Implementation of Curriculum 2013 integrated with STEM education, including 27 science teachers of junior high school, 35 physics teachers, 27 Chemistry teachers, and 31 Biology teachers spread in several regencies/cities in Indonesia.

\section{RESULTS AND DISCUSSION}

The Teacher Professional Development Program conducted by CDETEP in Science consisted of three stages, including 1) In-Service Training 1 (IN-1) using a face-to-face pattern for 60 credit hours; 2) On the Job Learning (OJL) using an online pattern for 70 credit hours; 3) In-Service Training 2 (IN-2) using a face-to-face pattern for 40 credit hours.

As shown in Figure 1, about $93 \%$ of respondents stated that the topics discussed throughout the IN-1 were effective in improving their knowledge and skills regarding STEM education.

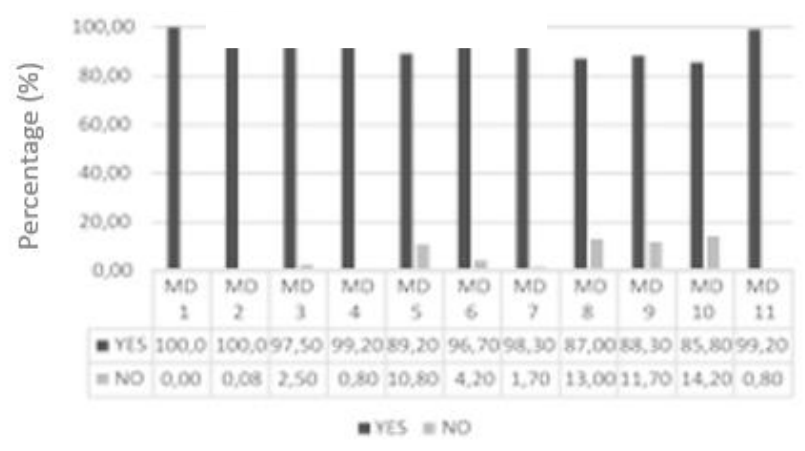

Fig. 1. Program effectiveness based on teacher competencies (MD)
This survey shows that respondents have benefitted after attending the Professional Development Program with the improvement of their knowledge about STEM education. It can be said that the Teacher Professional Development Program is one of the keys to improving the quality of STEM education [19].

Respondents also provided the reasons for their answers to the survey questions as shown in Table 1.

TABLE I. TARgET COMPETENCE OF A TRAINING COURSE

\begin{tabular}{|c|c|c|}
\hline MD & Competencies & $\begin{array}{c}\text { What Respondents Have } \\
\text { Learned }\end{array}$ \\
\hline 1. & $\begin{array}{l}\text { Understand the significance } \\
\text { of STEM approach }\end{array}$ & $\begin{array}{l}\text { Respondents understood that } \\
\text { STEM is one of the solutions to } \\
\text { improve critical thinking, } \\
\text { creativity, collaborative, } \\
\text { communicative, and problem- } \\
\text { solving skills. }\end{array}$ \\
\hline 2. & $\begin{array}{l}\text { Understand the framework } \\
\text { of STEM Education }\end{array}$ & $\begin{array}{l}\text { Respondents understood learning } \\
\text { model used in STEM education } \\
\text { and integrating it into a learning } \\
\text { project. }\end{array}$ \\
\hline 3. & $\begin{array}{l}\text { Identify the Basic } \\
\text { Competence and topics } \\
\text { from the curriculum } 2013 \\
\text { that can be taught using the } \\
\text { STEM approach }\end{array}$ & $\begin{array}{l}\text { Respondents selected the Basic } \\
\text { Competence associated with } \\
\text { problem-solving. }\end{array}$ \\
\hline 4. & $\begin{array}{l}\text { Integrate STEM in Science } \\
\text { learning }\end{array}$ & $\begin{array}{l}\text { Respondents were able to arrange } \\
\text { science learning using the STEM } \\
\text { approach }\end{array}$ \\
\hline 5. & $\begin{array}{l}\text { Develop an assessment } \\
\text { instrument of the STEM } \\
\text { approach }\end{array}$ & $\begin{array}{l}\text { Respondents were able to assess } \\
\text { STEM education in regards to } \\
\text { affective, cognitive, and } \\
\text { psychomotor aspects. }\end{array}$ \\
\hline 6. & $\begin{array}{l}\text { Develop a lesson plan of the } \\
\text { STEM approach }\end{array}$ & $\begin{array}{l}\text { Respondents developed the lesson } \\
\text { plan of the STEM approach on } \\
\text { another topic. }\end{array}$ \\
\hline 7. & $\begin{array}{l}\text { Gain teaching experience } \\
\text { using the STEM approach }\end{array}$ & $\begin{array}{l}\text { Respondents gained the idea of } \\
\text { how to implement STEM } \\
\text { education in class. }\end{array}$ \\
\hline 8. & $\begin{array}{l}\text { Use the features of the } \\
\text { online } \\
\text { management system }\end{array}$ & $\begin{array}{l}\text { Respondents learned the features } \\
\text { of the online management system } \\
\text { and used it. }\end{array}$ \\
\hline 9. & $\begin{array}{l}\text { Gain entrepreneurship in } \\
\text { learning }\end{array}$ & $\begin{array}{l}\text { Respondents realized the } \\
\text { idea/products of STEM education }\end{array}$ \\
\hline 10. & $\begin{array}{l}\text { Conduct educational } \\
\text { research to improve the } \\
\text { quality of learning using the } \\
\text { STEM approach }\end{array}$ & $\begin{array}{l}\text { Some respondents, who are used to } \\
\text { do research, did not experience } \\
\text { difficulties putting it into practice, } \\
\text { on the other hand, the unfamiliar } \\
\text { ones are unable to practice it. }\end{array}$ \\
\hline 11. & $\begin{array}{l}\text { The STEM Units (modules) } \\
\text { provide pictures on how to } \\
\text { develop STEM education } \\
\text { instruments }\end{array}$ & $\begin{array}{l}\text { Respondent understood the } \\
\text { framework in implementing STEM } \\
\text { education. }\end{array}$ \\
\hline
\end{tabular}

Respondents' statements reinforce the data that their knowledge about STEM education increases after participating in PD. Some respondents developed lesson plans and evaluations for other learning topics using the STEM approach.

There are some interesting notes stated by the respondents after participating in the program, for example: 
"... I found some new things that can be done with other fellow teachers. I am now designing a collaborative learning project among STEM education, Craft and Entrepreneur, English, and Scouts. I came up with this idea after implementing the STEM Units developed by CDETEP in Science. When I designed the learning activity independently, I thought that this integration is the solution to overcome the time constraint."

Other respondents were also willingly integrating STEM education into other subjects. This is very effective in dealing with the time constraint if the STEM approach is used. The integration of STEM education is possible due to the interconnection of several Basic Competences in the Curriculum 2013. This also can be implemented in other STEM Units or program because the integrated STEM provides better teaching experience and teachers can collaborate [20]. STEM education is intentionally merging the separate disciplines in order to solve real-world problems [21,22]. Real world context can be used to investigate authentic problems using active learning and teaching approaches. An authentic STEM education is expected to build students' conceptual knowledge of the inter-related nature of science and mathematics, in order to allow students to develop their understanding of engineering and technology [23]. The obstacles to implementing the integrated STEM are time constraints, lack of peer supports from fellow teachers, insufficient knowledge on the STEM topics, and insufficient numbers of training on STEM education [24,25].

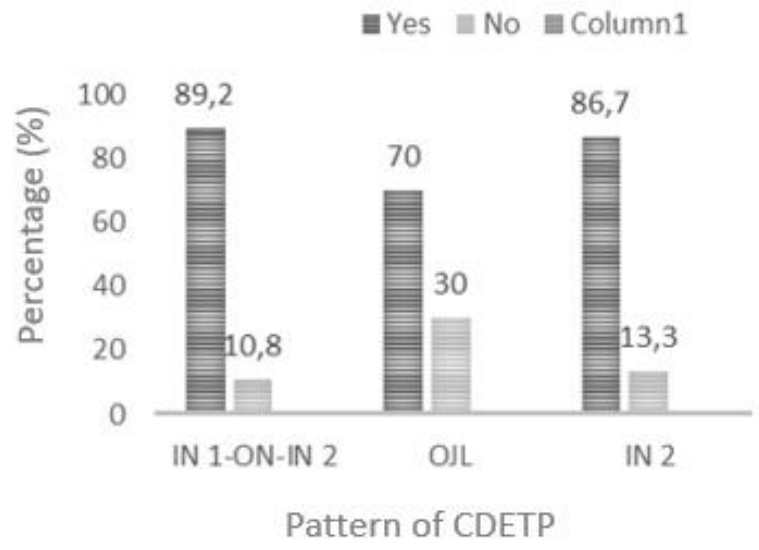

Fig. 2. Responses to IN-ON-IN Patterns, Online Supervision, and IN 2 Dissemination.

The training pattern used in the program was considered effective by $70 \%$ of respondents (shown in Figure 2). However, 30 of respondents stated that the online supervision was not effective because of several reasons including bad internet connection, poor time management, and lack of communication with the facilitator. These points could be taken as recommendations and suggestions for the program organizer to conduct online supervision more interesting. Below is the statement of a respondent concerning online supervision.
"Other activities of the facilitator and training participants lead to insufficient communication between the two. The time lag between the questions asked by the respondent and the answers from the facilitator is too long. It makes participants' motivation decrease. This is the reason why online supervision does not work as expected..."

From the statement above, it can be concluded that a special treat is required in the online stage of the program. The system should be interestingly developed, user friendly, and easy access. In addition, the material uploaded on the website also can be used by the teacher in the class [26].

After completing the program, 94,2\% of respondents are still implementing STEM education in class, especially the topics covered in the STEM Units developed by CDETEP in Science. The difficulties found by the respondents in implementing STEM education are lack of supports from surroundings, take too long, and students are reluctantly involved especially in doing the assignments. Regarding the supports from surroundings, STEM education will be successful if several teachers from one region participate in the program. This is needed after the training when they return to their places, there are still friends to discuss when they find difficulties in implementing STEM education. According to Guzey et al. [27] the program needs to be reformed to be more excellent by providing supervision and conducting interteacher discussion [2].

Improving Students' 21st-century skills during the implementation of STEM education is collaborative, critical thinking, creative, communicative, and problem-solving skills. $74,2 \%$ of respondents are still developing the lesson plan for STEM education. This implies that the professional development program is effective in delivering some important concepts of STEM education, however, continuous supervision is required to maintain the knowledge and skills they gain during the training [28]. Sustained profesional development followed by feedback is necessary. The more sustained profesional development, the more teachers learn from it [28, 29].

\section{CONCLUSIONS}

Based on data analysis and discussion, it can be concluded that the topics of the IN-1 were effective to improve respondents' competence as supported by $93 \%$ of respondents; $70 \%$ of respondents stated that the training pattern used in IN-1 (face-to-face)-OJL (online supervision)-IN-2 (Dissemination in MGMP) is effective for teacher professional development program; and $94,2 \%$ of respondents still implement STEM education in class. According to the respondent, the student's collaborative, communicative, critical thinking, and creative skills are improved. Then we can conclude that STEM education is effective for improving students' 21 st century skills. Therefore, sustained professional development in STEM education is needed, so that the student's 21 st century skills are better trained and become a habit. 


\section{REFERENCES}

[1] K. Lesseig, T.H. Nelson, D. Slavit, and R.A. Seidel, "Supporting Middle School Teachers' Implementation of STEM Design Challenges: Middle School STEM Design Challenges,” Sch. Sci. Math., vol. 116, no. 4, pp. 177-188, Apr. 2016.

[2] S.M. Stehle and E.E. Peters-Burton, "Developing student 21st Century skills in selected exemplary inclusive STEM high schools," Int. J. STEM Educ., vol. 6, no. 1, p. 39, Dec. 2019.

[3] T.R. Guskey and K.S. Yoon, "What Works in Professional Development?,” Phi Delta Kappan, vol. 90, no. 7, pp. 495-500, Mar. 2009.

[4] L.S. Nadelson, J. Callahan, P. Pyke, A. Hay, M. Dance, and J. Pfiester, "Teacher STEM Perception and Preparation: Inquiry-Based STEM Professional Development for Elementary Teachers," J. Educ. Res., vol. 106, no. 2, pp. 157-168, Feb. 2013.

[5] B. Wahono and C.-Y. Chang, "Assessing Teacher's Attitude, Knowledge, and Application (AKA) on STEM: An Effort to Foster the Sustainable Development of STEM Education," Sustainability, vol. 11, no. 4, p. 950, Feb. 2019

[6] S. Kanadl1, "A Meta-Summary of Qualitative Findings about STEM Education,” Int. J. Instr., vol. 12, no. 1, pp. 959-976, Jan. 2019.

[7] M.S. Garet, A.C. Porter, L. Desimone, B.F. Birman, and K.S. Yoon, "What Makes Professional Development Effective? Results From a National Sample of Teachers," Am. Educ. Res. J., vol. 38, no. 4, pp. 915-945, Jan. 2001

[8] D.J. Shernoff, S. Sinha, D.M. Bressler, and L. Ginsburg, "Assessing teacher education and professional development needs for the implementation of integrated approaches to STEM education," Int. J. STEM Educ., vol. 4, no. 1, p. 13, Dec. 2017.

[9] G.A. Fore, C.R. Feldhaus, B.H. Sorge, M. Agarwal, and K Varahramyan, "Learning at the nano-level: Accounting for complexity in the internalization of secondary STEM teacher professional development," Teach. Teach. Educ., vol. 51, pp. 101-112, Oct. 2015

[10] B. Avalos, "Teacher professional development in Teaching and Teacher Education over ten years," Teach. Teach. Educ., vol. 27, no. 1, pp. 1020, Jan. 2011.

[11] D. DiFrancesca, C. Lee, and E. McIntyre, "Where Is the 'E' in STEM for Young Children?," vol. 23, no. 1, p. 16, 2014.

[12] T.L. Coskie and N.A. Place, "The National Board certification process as professional development: The potential for changed literacy practice," Teach. Teach. Educ., vol. 24, no. 7, pp. 1893-1906, Oct. 2008.

[13] S.S. Bartholomew and J.H. Sandholtz, "Competing views of teaching in a school-university partnership,” Teach. Teach. Educ., vol. 25, no. 1, pp. 155-165, Jan. 2009.

[14] L. Ingvarson, M. Meiers, and A. Beavis, "Factors affecting the impact of professional development programs on teachers' knowledge, practice, student outcomes \& efficacy.,” Educ. Policy Anal. Arch., vol. 13, p. 10, Jan. 2005.
[15] D.A. Breault and R. Breault "Partnerships for preparing leaders: what can we learn from PDS research?,” Int. J. Leadersh. Educ., vol. 13, no. 4, pp. 437-454, Oct. 2010

[16] J.W. Creswell, Educational research: planning, conducting, and evaluating quantitative and qualitative research, 4th ed. Boston: Pearson, 2012.

[17] D.L. Kirkpatrick and J.D. Kirkpatrick, Evaluating training programs: the four levels, 3rd ed. San Francisco, CA: Berrett-Koehler, 2006.

[18] J.R. Fraenkel, N.E. Wallen, and H.H. Hyun, How to design and evaluate research in education, 8th ed. New York: McGraw-Hill Humanities/Social Sciences/Languages, 2012.

[19] K.P.S. Goodpaster, O.A. Adedokun, and G.C. Weaver, "Teachers' Perceptions of Rural STEM Teaching: Implications for Rural Teacher Retention," Rural Educ., vol. 33, no. 3, Nov. 2018.

[20] K. Al Salami, C.J. Makela, and M.A. de Miranda, "Assessing changes in teachers' attitudes toward interdisciplinary STEM teaching," Int. J. Technol. Des. Educ., vol. 27, no. 1, pp. 63-88, Mar. 2017

[21] J.B. Labov, A.H. Reid, and K.R. Yamamoto, "Integrated Biology and Undergraduate Science Education: A New Biology Education for the Twenty-First Century?," CBE-Life Sci. Educ., vol. 9, no. 1, pp. 10-16, Mar. 2010.

[22] M. Sanders, "Integrative Stem Education As 'Best Practice,"” p. 15.

[23] P.R. Hernandez, R. Bodin, J.W. Elliott, B. Ibrahim, K.E. RamboHernandez, T.W. Chen and M.A. de Miranda, "Connecting the STEM dots: measuring the effect of an integrated engineering design intervention," International journal of Technology and design Education, vol. 24, no. 1, pp. 107-120, 2014.

[24] H. Park, S. Byun, J. Sim, H.-S. Han, and Y.S. Baek, "Teachers' Perceptions and Practices of STEAM Education in South Korea," EURASIA J. Math. Sci. Technol. Educ., vol. 12, no. 7, Apr. 2016.

[25] M.-H. Park, D.M. Dimitrov, L.G. Patterson, and D.-Y. Park, "Early childhood teachers' beliefs about readiness for teaching science, technology, engineering, and mathematics," J. Early Child. Res., vol. 15, no. 3, pp. 275-291, Sep. 2017.

[26] P. Beach, "Self-directed online learning: A theoretical model for understanding elementary teachers' online learning experiences," Teach. Teach. Educ., vol. 61, pp. 60-72, Jan. 2017.

[27] S.S. Guzey, K. Tank, H.-H. Wang, G. Roehrig, and T. Moore, "A HighQuality Professional Development for Teachers of Grades 3-6 for Implementing Engineering into Classrooms: Engineering Integration," Sch. Sci. Math., vol. 114, no. 3, pp. 139-149, Mar. 2014.

[28] S. Han, B. Yalvac, M.M. Capraro, and R.M. Capraro, "In-service Teachers' Implementation andUnderstanding of STEMProject Based Learning,” EURASIA J. Math. Sci. Technol. Educ., vol. 11, no. 1, Dec. 2015.

[29] R.M. Capraro, M.M. Capraro, J.J. Scheurich, M. Jones, J. Morgan, K.S Huggins, and S. Han, "Impact of sustained professional development in STEM on outcome measures in a diverse urban district," J. Educ. Res. vol. 109, no. 2, pp. 181-196, Mar. 2016. 